\title{
LOWER EXTREMITY PROBLEMS AND RELATED SURGICAL PROCEDURES BEFORE AND DURING THE COVID-19 PANDEMIC IN A TERTIARY HEALTHCARE INSTITUTION
}

\author{
Abdullah Alper Sahin, ${ }^{1}$ Emced Khali ${ }^{2}$ \\ ${ }^{1}$ Ordu University Training and Research Hospital, Department of Orthopaedic and Traumatology, Ordu, Turkey \\ ${ }^{2}$ Ordu University Training and Research Hospital, Departınent of Cardiovasçular Surgery, Ordu, Turkey
}

Primljen/Received 02. 06. 2020. god.

Prihvaćen/Accepted 28. 06. 2021. god.

Abstract: Aim: This study aims to investigate whether there was a change in the number of elective surgical procedures and outpatient presentations between the first and second episodes of COVID-19 in a tertiary center in Turkey.

Methods: This retrospective study included data concerning patients presenting to the outpatient and emergency departments of orthopedics and vascular surgery and undergoing surgery in these departments during the first (March-April, 2020) and the second episodes (November-December, 2020) of COVID-19 in a tertiary center in Turkey.

Results: When the procedures related to orthopedics and traumatology were examined, compared to 2019 , the total number of examinations, emergency patients, surgeries, total knee replacement, total hip replacement decreased in 2020, it was seen that the numbers of lower extremity fracture and lower limb amputation increased (both in March-April and November-December periods). When lower extremity vascular procedures were analyzed, we found that the number of all procedures decreased in 2020 compared to 2019 (both in March-April and November-December periods).

Conclusion: Our findings show there was a slight increase in admissions to outpatient and emergency departments of orthopedics and vascular surgery department as well as the number of surgical procedures performed during the second episode of the COVID-19 outbreak compared to the first episode. However, both outpatient and emergency department admissions were lower than that of the pre-COVID era, as well as the number of surgical procedures.

Keywords: orthopedic procedures, SARS-CoV-2, vascular surgical procedures.

\section{INTRODUCTION}

The first cases of severe pneumonia with unknown etiology were seen in Wuhan, China, at the end of 2019 (1). Fever, shortness of breath, sore throat, and cough were the initial symptoms (2). Chinese Center for Disease Control and Prevention (CDC) identified a novel coronavirus from the throat swab sample from a patient presenting with these symptoms. World Health Organization (WHO) further named the novel coronavirus as $2019 \mathrm{nCoV}$ (3). The International Committee on Taxonomy of Viruses renamed the virus a severe acute respiratory syndrome coronavirus-2(SARS-CoV-2) by February 2020 (4). The epidemic disease caused by SARS-CoV-2 was further announced by WHO as coronavirus disease 2019 (COVID-19). COVID-19 was qualified as a pandemic by the World Health Organization (WHO) on March 11, 2020 (5).

By the end of February 2021, about 10 million people have been infected by SARS-CoV-2. Approximately 2.3 million deaths were caused by COVID-19 globally (6). The initial phase of COVID-19 pandemics was associated with a stunning healthcare network due to the excessive burden on emergency departments and intensive care units. Almost all countries worldwide declared a state of alarm against the increasing number of COVID-19 cases to reduce the heavy burden on the healthcare system. Elective interventional and surgical procedures were also postponed due to the burden on the healthcare systems loaded by COVID-19 cases (7). People's fear of being infected by SARS-CoV-2, with no reliable treatment provided at the initial phase of the pandemic, restricted individuals seeking medical care for their acute or chronic diseases other than COVID-19. Several reports have shown a significant 
decline in the number of individuals presenting to the emergency department even with symptoms of potentially life-threatening conditions such as acute coronary syndromes compared to the pre-pandemics era (8). During the COVID-19 pandemic, governments re-organized healthcare systems according to accumulating evidence concerning the spread and treatment of the COVID-19. There was a relative decline in COVID-19 cases in Turkey by June 2020. A gradual loosening in social restriction measurements was then carried out. However, the second episode of the COVID-19 outbreak was observed again between November and December 2020 (9). Although there was a significant decline in the numbers of elective surgical procedures and outpatient presentations in the first episode of COVID-19, whether there was a different trend in this second episode of COVID-19 in Turkey is unknown.

This study aimed to investigate whether there was a change in the number of elective surgical procedures and outpatient presentations between the first and second episode of COVID-19 in a tertiary center in Turkey.

\section{MATERIALS AND METHODS}

\section{Study setting and design}

This retrospective study included data concerning the patients presenting to outpatient and emergency departments of orthopedics and vascular surgery and undergoing surgery in these departments in the first (March-April, 2020) and second episodes (November-December, 2020) of COVID-19 in a tertiary center in Turkey.

\section{Methods}

All patients scheduled for surgery at the aforementioned departments underwent PCR tests for COVID-19, and those with positive PCR test results were excluded. Written informed consent was obtained from all sub- jects. Ethical approval for the study was obtained from Ordu University Clinical Research Ethics Committee ( No 2021/72). The study was conducted in accordance with the Helsinki declaration. Statistical data, concerning the outpatient presentation and surgical procedures performed in orthopedics and vascular surgery departments at the same time intervals of 2019, were retrieved from the institutional digital database.

The primary outcome measure of this study was the difference in the outpatient presentation numbers and the number of the surgical procedures performed at orthopedics and vascular surgery departments following the COVID 19 outbreak. The secondary outcome measure was the difference in the outpatient presentation numbers and the number of the surgical procedures performed at orthopedics and vascular surgery departments between the first and the second episode of the COVID-19 outbreak in Turkey.

\section{Statistical analysis}

All analyses were performed on SPSS v21 (SPSS Inc., Chicago, IL, USA). Data are given as frequency (percentage) for categorical variables.

\section{RESULTS}

When the procedures related to orthopedics and traumatology are examined, compared to 2019, while the total number of examinations, emergency patients, surgeries, total knee replacement, total hip replacement decreased in 2020, it was seen that the numbers of lower extremity fracture and lower limb amputation increased (both in March-April and November-December periods) (Table 1).

When lower extremity vascular procedures were analyzed, we found that the number of all procedures decreased in 2020 compared to 2019 (both in MarchApril and November-December periods) (Table 2).

Table 1. Distribution of orthopedics and traumatology examinations and surgeries according to the period

\begin{tabular}{|l|c|c|}
\hline \multirow{2}{*}{} & \multicolumn{2}{|c|}{ Period } \\
\cline { 2 - 3 } & March - April & November - December \\
\hline Total number of examinations & $4191 / 1741$ & $6318 / 2249$ \\
\hline Total number of emergency patients & $35 / 13$ & $36 / 16$ \\
\hline Total number of surgeries & $251 / 130$ & $252 / 145$ \\
\hline Type of surgery & $68 / 9$ & $48 / 16$ \\
\hline Total knee replacement & $11 / 1$ & $12 / 5$ \\
\hline Total hip replacement & $19 / 34$ & $41 / 50$ \\
\hline Lower extremity fracture & $6 / 10$ & $3 / 8$ \\
\hline Lower limb amputation & & \\
\hline
\end{tabular}


Table 2. Distribution of lower extremity vascular examinations and surgeries according to the period

\begin{tabular}{|l|c|c|}
\hline \multirow{2}{*}{} & \multicolumn{2}{|c|}{ Period } \\
\cline { 2 - 3 } & March - April & November - December \\
\hline Total number of examinations & $811 / 104$ & $641 / 310$ \\
\hline Total number of emergency patients & $16 / 2$ & $11 / 6$ \\
\hline Type of surgery & $7 / 0$ & $12 / 4$ \\
\hline Deep vein thrombosis & $72 / 0$ & $60 / 0$ \\
\hline Varicosis & $4 / 1$ & $3 / 2$ \\
\hline Embolectomy & $8 / 0$ & $9 / 1$ \\
\hline Fem-Pop bypass & $1 / 0$ & $2 / 0$ \\
\hline Extra-anatomic bypass & $28 / 0$ & $32 / 5$ \\
\hline Endovascular therapy & & \\
\hline
\end{tabular}

Data are given as frequency (2019/2020).

Our findings show that the COVID-19 outbreak can be associated with a decline in presentations in the emergency department and outpatient clinics of orthopedics and vascular surgery. An increase in the number of patients, presenting to the emergency department and outpatient clinics of orthopedics and vascular sur-

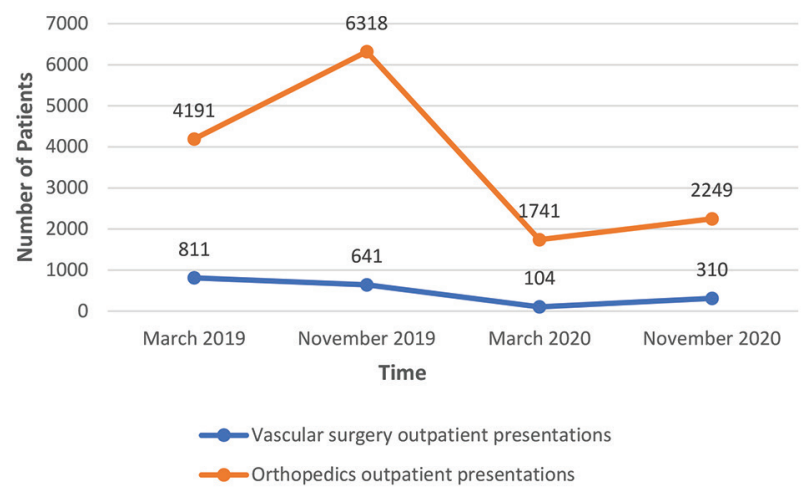

Figure 1. The change in the number of admissions to the outpatient clinic of orthopedics and vascular surgery before and after the first and the second episodes of the COVID-19

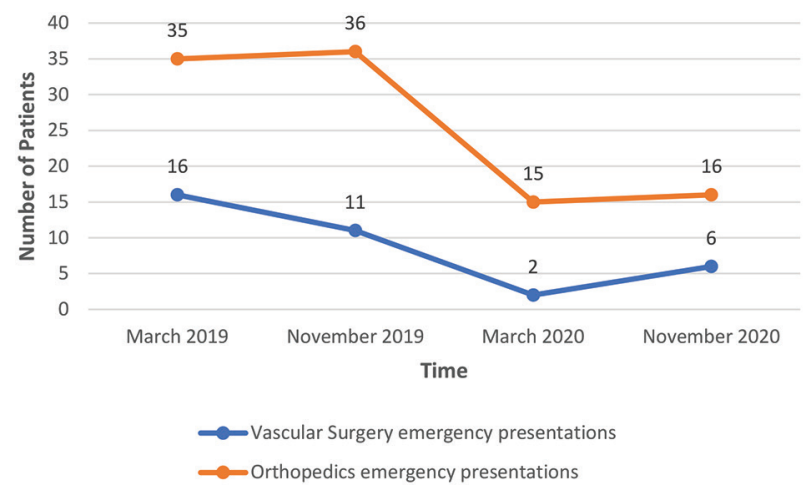

Figure 2. The change in the number of admissions to the emergency department for musculoskeletal and vascular causes before and after the first and the second episodes of the COVID-19 gery, was observed from the first to the second episode of the COVID-19 outbreak; however, it was still lower than that of the same period of 2019 (Figure 1 and 2).

The number of patients undergoing intervention or surgery for deep vein thrombosis, varicose veins, or lower extremity arterial disease (femoropopliteal
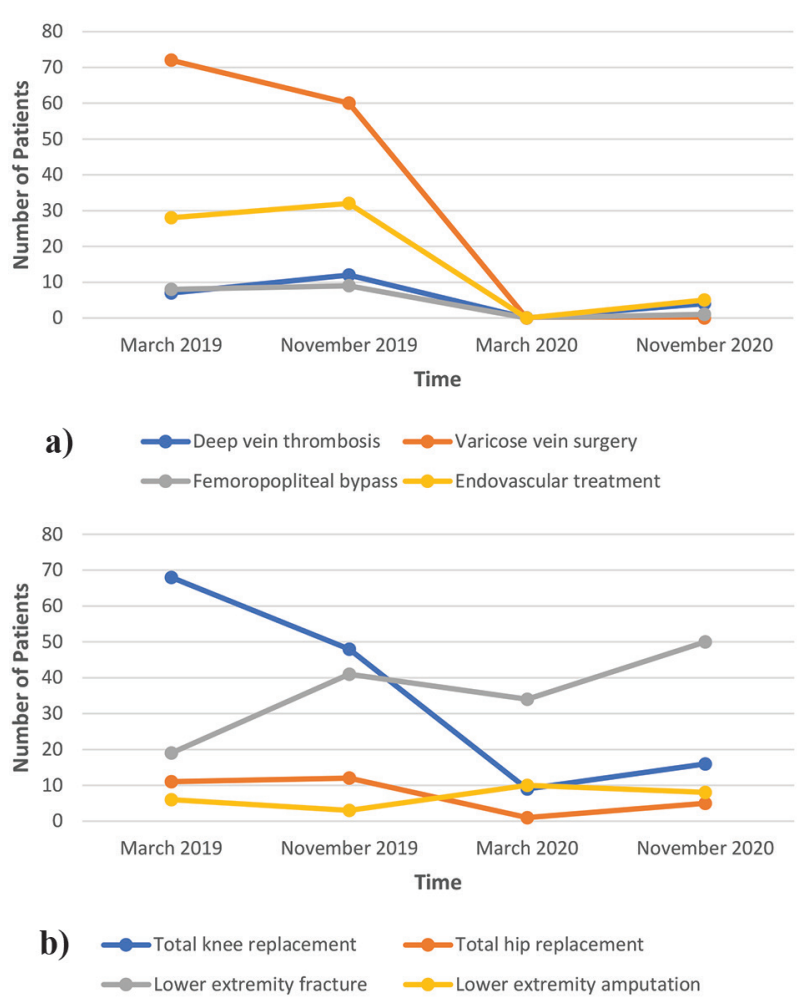

Figure 3. (a)The change in the number of interventional and surgical procedures performed by vascular surgery departments before and after the first and the second episodes of the COVID-19.

(b) The change in the number of interventional and surgical procedures performed by orthopedics departments before and after the first and the second episodes of the COVID-19 
bypass, endovascular treatment) demonstrated a steep decline following the COVID-19 outbreak, although a slight increase was observed from the first to the second episode. However, the number of patients undergoing interventions for the aforementioned conditions was still lower at the second episode of COVID-19 compared to the same period of 2019 (Figure 3).

A similar trend was observed in orthopedics surgery. The number of patients undergoing total knee and hip replacement and lower extremity amputation demonstrated a steep decline following the COVID-19 outbreak, although a slight increase was observed from the first to the second episode. As an interesting finding, the number of patients presenting with lower extremity fractures increased following the COVID-19 outbreak, and this increase continued at the second episode of the COVID-19 outbreak (Figure 3).

\section{DISCUSSION}

Findings show that the number of patients admitted to the emergency department and outpatient clinic on our institute for vascular surgery and orthopedics in the COVID-19 era was lower compared to the same interval of last year. However, there was a slight increase in presentations to the emergency department and outpatient clinic of orthopedics and vascular surgery departments from the first to the second episode of the COVID-19 outbreak. Our findings also show that the number of patients presenting for surgical and interventional procedures to the orthopedics and vascular surgery departments demonstrated a steep decline following the COVID-19 outbreak. However, a slight increase was observed from the first to the second episode. Nevertheless, the number of patients undergoing surgical procedures in orthopedics and vascular surgery departments in the second episode of the COVID-19 outbreak was still lower than that of the same period of 2019 .

The COVID-19 outbreak led to significant changes in health policies and influenced the public to seek medical help even for acute life-threatening conditions. Previous data from France, Spain, Austria, and United States have shown that admissions for acute coronary syndromes and the number of emergency cardiac interventions demonstrated a significant decline following the emergence of the COVID-19 outbreak (10-13). A recent study from Turkey has shown a similar decline in the number of patients admitted to the emergency department with cardiovascular symptoms, acute heart failure, acute coronary syndrome, STEMI, and in diagnostic angiographies, peripheral endovascular interventions, and cardiac surgeries (8). This was somewhat explained by the strict contain- ment measures that made individuals hesitate to admit to hospitals to prevent being infected by the SARS$\mathrm{CoV}-2$. The declaration of the state of alarm by many countries and related containment measures with the public-health messages have resulted in self-censorship to prevent possible contamination in hospitals (14). However, the acute burden on the healthcare system resulting from high numbers of COVID-19 admissions led to a change in the structure of the healthcare organization in hospitals. Many outpatient clinics and ICU units were reserved for diagnosing and managing COVID-19 patients $(15,16)$. However, this further led to collateral damage which could be described as the increase in comorbidities and deaths caused by severe medical conditions that require hospital admission and emergent intervention.

Studies have been conducted to examine the number of hospital admissions during the early period of the COVID-19 pandemic. A study conducted in a university hospital emergency in Turkey determined there was a decrease in the rate of total admissions to the emergency department (from $49.9 \%$ to $33.2 \%$ ) in April compared to March when the first case was announced (17). The results of the studies evaluating the decrease in the number of hospital admissions compared to the previous year in the first periods of the COVID-19 pandemic were as follows, $42 \%$ decrease in the USA between March 29 and April 25, 2020 (18), 50\% decrease in the UK between March 2 and May 3 (19), 47\% decrease in France between March 23-April 5 (20). Similarly, in studies conducted in many countries in the later stages of the pandemic, it was reported that there was a significant decrease in hospital admissions $(21,22,23)$. The results of our study were similar to the hospital admissions trend in different countries.

Several vascular and orthopedics conditions require surgical or interventional procedures for management. These include lower extremity fractures, lower extremity amputations, deep vein thrombosis that requires pharmaco-mechanical treatment, and lower extremity arterial disease which should be managed by femoropopliteal bypass and endovascular strategies $(24,25,26)$. This study showed that the COVID-19 outbreak has led to increased admissions for bone fractures and amputation. The common belief was that the number of procedures has increased because patients with peripheral artery disease cannot be fully treated with medical or therapeutic intervention during the pandemic period.

By the course of the COVID-19 pandemics, the containment measures and the state of alarm brought favorable results indicated by the reduced number of admissions for COVID-19 (27-30). In addition, the collateral damage and the increased morbidity and 
mortality resulting from other critical medical conditions led to a change in health policies (31-34). Individuals with symptoms of critical medical conditions were then encouraged to present in emergency departments for seeking medical help. However, the second episode of the COVID-19 outbreak occurred between November and December 2020. Our findings show that public experience derived from the first episode and establishment of preventative measures led to more outpatient clinic and emergency department admissions during the second episode. However, the number of patients in outpatient clinics and emergency departments, as well as the interventional and surgical procedures performed during the second episode of the COVID-19, were still lower than that last year. This may still lead to an increase in morbidity and mortality from serious clinical conditions other than COVID-19. Given that an integrated healthcare system should not only focus on the COVID-19 outbreak but also consider the consequences of other serious clinical conditions, the healthcare system should seek ways to manage acute musculoskeletal and vascular disorders, which may potentially be lethal, during pandemics.

\section{CONCLUSION}

Our findings show a slight increase in admissions to outpatient and emergency departments of orthopedics and vascular surgery department along with surgical procedures performed by these disciplines during the second episode of the COVID-19 outbreak compared to the first episode. That said, outpatient and emergency department admissions and the number of surgical procedures were still lower than in the preCOVID era. The healthcare system should focus on finding ways to manage serious clinical conditions other than COVID-19 to reduce the morbidity and mortality resulting from these conditions.

\section{Acknowledgment}

None.

Conflict of Interests: The authors declare that there are no conflicts of interest related to this article.

Funding: None

\section{Licensing}

This work is licensed under a Creative Commons Attribution 4.0 International (CC BY 4.0) License.

\title{
Sažetak
}

\section{PROBLEMI DONJIH EKSTREMITETA I HIRURŠKI ZAHVATI POVEZANI SA NJIMA PRE I TOKOM PANDEMIJE COVID-19 U TERCIJARNOJ ZDRAVSTVENOJ USTANOVI}

\author{
Abdullah Alper Sahin, ${ }^{1}$ Emced Khalil ${ }^{2}$ \\ ${ }^{1}$ Ordu University Training and Research Hospital, Department of Orthopaedic and Traumatology, Ordu, Turkey \\ ${ }^{2}$ Ordu University Training and Research Hospital, Departınent of Cardiovasçular Surgery, Ordu, Turkey
}

Cilj: Ova studija ima za cilj da istraži da li je došlo do promene u broju elektivnih hirurških zahvata i ambulantnih pregleda između prve i druge epizode COVID-19 u tercijarnom centru u Turskoj.

Metode: Ova retrospektivna studija obuhvatila je podatke o pacijentima koji su se javljali ambulantno $i$ na odeljenja urgentne ortopedije i vaskularne hirurgije i bili operisani na tim odeljenjima tokom prve (mart-april 2020.) i druge epizode (novembar-decembar 2020.) COVID-a -19 u tercijarnom centru u Turskoj.

Rezultati: Kada su pregledani zahvati vezani za ortopediju i traumatologiju, u odnosu na 2019. godinu, ukupan broj pregleda, hitnih pacijenata, operacija, totalne zamene kolena, totalne zamene kuka se smanjio 2020. godine, uočeno je da je broj preloma donjih ekstremiteta i amputacija donjih ekstremiteta povećan (i u periodu mart-april i u periodu novembar-decembar). Kada su analizirane vaskularne procedure donjih ekstremiteta, otkrili smo da se broj svih zahvata smanjio u 2020. u odnosu na 2019. (u periodu mart-april i novembar-decembar).

Zaključak: Naši nalazi pokazuju da je došlo do blagog povećanja ambulantnih pregleda i prijema na odeljenja urgentne ortopedije i vaskularne hirurgije, kao i broja hirurških zahvata obavljenih tokom druge epizode izbijanja KOVID-19 u odnosu na prvu epizodu. Međutim, broj ambulantnih i hitnih prijema bio je manji nego u doba pre KOVID-a, kao i broj hirurških zahvata.

Ključne reči: ortopedski zahvati, SARS-CoV-2, vaskularni hirurški zahvati. 


\section{REFERENCES}

1. Wang D, Hu B, Hu C, Zhu F, Liu X, Zhang J, et al. Clinical characteristics of 138 hospitalized patients with 2019 novel coronavirus-infected pneumonia in Wuhan, China. JAMA. 2020; 323(11): 1061-9. doi: 10.1001/jama.2020.1585.

2. Harapan H, Itoh N, Yufika A, Winardi W, Keam S, Te $\mathrm{H}$, et al. Coronavirus disease 2019 (COVID-19): A literature review. Journal of infection and public health 2020. J Infect Public Health. 2020; 13(5): 667-673. doi: 10.1016/j.jiph.2020.03.019.

3. Huang C, Wang Y, Li X, Ren L, Zhao J, Hu Y, et al. Clinical features of patients infected with 2019 novel coronavirus in Wuhan, China. Lancet. 2020; 395(10223): 497-506. doi: 10.1016/S0140-6736(20)30183-5.

4. Ge H, Wang X, Yuan X, Xiao G, Wang C, Deng T, et al. The epidemiology and clinical information about COVID-19. Eur J Clin Microbiol Infect Dis. 2020; 39(6): 1011-9. doi: 10.1007/s10096-020-03874-z.

5. Velavan TP, Meyer CG. The COVID-19 epidemic. Trop Med Int Health 2020; 25(3): 278-80. doi: 10.1111/tmi.13383.

6. Organization WHO. World Health Organization. Weekly epidemiological update - 16 February 2021: WHO; 2021 [cited 202120 February]. Available from: https://www. who.int/publications/m/item/weekly-epidemiological-update---16-february-2021.

7. Diaz A, Sarac BA, Schoenbrunner AR, Janis JE, Pawlik TM. Elective surgery in the time of COVID-19. Am J Surg. 2020; 219(6): 900-2. doi: 10.1016/j.amjsurg.2020.04.014.

8. Khalil E, Ozcan S. Comparison of the number of cardiovascular admissions before and after covid-19: Experience from Turkey. Acta Medica Mediterranea. 2020; 36(4): 2433-7.

9. Durmuş V. Epidemic trends of COVID-19 in 10 countries compared with Turkey. Vacunas. 2021; 22(1): 10-9. doi: 10.1016/j.vacun.2020.08.003

10. Huet F, Prieur C, Schurtz G, Gerbaud E, Manzo-Silberman S, Vanzetto G, et al. One train may hide another: Acute cardiovascular diseases could be neglected because of the COVID-19 pandemic. Arch Cardiovasc Dis. 2020; 113(5): 3037. doi: 10.1016/j.acvd.2020.04.002.

11. De Rosa S, Spaccarotella C, Basso C, Calabrò MP, Curcio A, Filardi PP, et al. Reduction of hospitalizations for myocardial infarction in Italy in the COVID-19 era. Eur Heart J. 2020; 41(22): 2083-8. doi: 10.1093/eurheartj/ehaa409.

12. Metzler B, Siostrzonek P, Binder RK, Bauer A, Reinstadler SJ. The decline of acute coronary syndrome admissions in Austria since the outbreak of COVID-19: the pandemic response causes cardiac collateral damage. Eur Heart J. 2020; 41(19): 1852-3. doi: 10.1093/eurheartj/ehaa314.

13. Garcia S, Albaghdadi MS, Meraj PM, Schmidt C, Garberich R, Jaffer FA, et al. Reduction in ST-segment elevation cardiac catheterization laboratory activations in the United States during COVID-19 pandemic. J Am Coll Cardiol 2020; 75(22): 2871-2. doi: 10.1016/j.jacc.2020.04.011.

14. Feral-Pierssens A-L, Claret P-G, Chouihed T. Collateral damage of the COVID-19 outbreak: expression of concern. Eur J Emerg Med. 2020; 27(4): 233-4. doi: 10.1097/ MEJ.0000000000000717.

15. Shoukat A, Wells CR, Langley JM, Singer BH, Galvani AP, Moghadas SM. Projecting demand for critical care beds during COVID-19 outbreaks in Canada. CMAJ. 2020; 192(19): 489-96. doi: 10.1503/cmaj.200457.
16. Ma X, Vervoort D. Critical care capacity during the COVID-19 pandemic: global availability of intensive care beds J Crit Care. 2020; 58: 96-7. doi: 10.1016/j.jcrc.2020.04.012.

17. Açiksari K, Kinik K. Türkiye'de bir Eğitim Araștırma Hastanesi Acil Servisinde Koronavirus Hastalığ 2019 Pandemi Sürecinin Yönetimi ve Sonuçları (TR/ENG). Anadolu Kliniği Tıp Bilimleri Dergisi. 2020; 25: 263-83. doi: 10.21673/ anadoluklin. 740776.

18. Hartnett K, Kite-Powell A, Devies J, Coletta M, Boehmer T, Adjemian J, et al. Impact of the COVID-19 pandemic on emergency department visits - United States, January 1, 2019 May 30, 2020. MMWR Morb Mortal Wkly Rep. 2020; 69(23): 699-704. doi: 10.15585/mmwr.mm6923e1.

19. Shanmugavadivel D, Liu J-F, Gilhooley C, Elsaadany L, Wood D. Changing patterns of emergency paediatric presentations during the first wave of COVID-19: learning for the second wave from a UK tertiary emergency department. BMJ paediatrics open. 2021; 15;5(1): e000967. doi: 10.1136/bmjpo-2020-000967.

20. Montagnon R, Rouffilange L, Agard G, Benner P, Cazes N, Renard A. Impact of the COVID-19 pandemic on emergency department use: focus on patients requiring urgent revascularization. J Emerg Med. 2021; 60(2): 229-236. doi: 10.1016/j.jemermed.2020.09.042.

21. Choi DH, Jung JY, Suh D, Choi JY, Lee SU, Choi YJ, et al. Impact of the COVID-19 Outbreak on Trends in Emergency Department Utilization in Children: a Multicenter Retrospective Observational Study in Seoul Metropolitan Area, Korea. J Korean Med Sci. 2021; 36(5): e44. doi: 10.3346/ jkms.2021.36.e44.

22. Chen JY-H, Chang F-Y, Lin C-S, Wang C-H, Tsai S-H, Lee C-C, et al. Impact of the COVID-19 Pandemic on the Loading and Quality of an Emergency Department in Taiwan: Enlightenment from a Low-Risk Country in a Public Health Crisis. J Clin Med. 2021; 10(6): 1150. doi: 10.3390/jcm10061150.

23. Slagman A, Behringer W, Greiner F, Klein M, Weismann D, Erdmann B, et al. Medical emergencies during the COVID-19 pandemic. Dtsch Arztebl Int. 2020; 117(33-34): 545-52. doi: 10.3238/arztebl.2020.0545.

24. Vedantham S, Goldhaber SZ, Julian JA, Kahn SR, Jaff MR, Cohen DJ, Magnuson E, Razavi MK, Comerota AJ, Gornik HL. Pharmacomechanical catheter-directed thrombolysis for deep-vein thrombosis. N Engl J Med. 2017; 377(23): 2240-52. doi: 10.1056/NEJMoa1615066.

25. Tintle LSM, Keeling CJJ, Shawen LSB, Forsberg LJA, Potter MBK. Traumatic and trauma-related amputations: part I: general principles and lower-extremity amputations. J Bone Joint Surg Am. 2010; 92(17): 2852-68. doi: 10.2106/JBJS.J.00257.

26. Antoniou GA, Chalmers N, Georgiadis GS, Lazarides MK, Antoniou SA, Serracino-Inglott F, et al. A meta-analysis of endovascular versus surgical reconstruction of femoropopliteal arterial disease. J Vasc Surg. 2013; 57(1): 242-53. doi: 10.1016/j.jvs.2012.07.038.

27. Deb P, Furceri D, Ostry JD, Tawk N. The effect of containment measures on the COVID-19 pandemic. 2020. https://www.imf.org/en/Publications/WP/Issues/2020/08/07/ The-Effect-of-Containment-Measures-on-the-COVID-19-Pandemic-49572.

28. Dickson MM, Espa G, Giuliani D, Santi F, Savadori L. Assessing the effect of containment measures on the Spa- 
tio-temporal dynamic of COVID-19 in Italy. Nonlinear Dyn. 2020: 1-14. doi: 10.1007/s11071-020-05853-7.

29. Signorelli C, Scognamiglio T, Odone A. COVID-19 in Italy: impact of containment measures and prevalence estimates of infection in the general population. Acta Biomed. 2020; 91(3-S): 175-179. doi: 10.23750/abm.v91i3-S.9511.

30. De Brouwer E, Raimondi D, Moreau Y. Modeling the COVID-19 outbreaks and the effectiveness of the containment measures adopted across countries. Cold Spring Harbor Laboratory; 2020 Apr 4; Available from: http://dx.doi. org/10.1101/2020.04.02.20046375

31. Sud A, Jones ME, Broggio J, Loveday C, Torr B, Garrett $\mathrm{A}$, et al. Collateral damage: the impact on outcomes from cancer surgery of the COVID-19 pandemic. Ann Oncol. 2020; 31(8): 1065-74. doi: 10.1016/j.annonc.2020.05.009.

32. Shepherd J, Friedland G. Preventing COVID-19 collateral damage. Clin Infect Dis 2020; 71(6): 1564-7. doi: 10.1093/cid/ciaa772.

33. Vervoort D, Luc JG, Percy E, Hirji S, Lee R. Assessing the collateral damage of the Novel Coronavirus: a call to action for the post-COVID-19 era. Ann Thorac Surg. 2020; 110(3): 757-60. doi: 10.1016/j.athoracsur.2020.04.015.

34. Masroor S. Collateral damage of COVID-19 pandemic: delayed medical care. J Card Surg. 2020; 35(6): 1345-7. doi: 10.1111/jocs. 14638 .

\section{Correspondence to/Autor za korespondenciju}

Abdullah Alper SAHIN, Assisa1t Professor, MD.

Ordu University Training and Reşearch Hospital,

Department of Orthopaedic and Traurnatology, Ord11, Turkey.

Telephone: +90 -537-596-09-14

Fax: +90-452-225-01-90

E-mail: dr.a.alpersahin@gmail.com

ORCID: 0000-0002-8973-2050 